\title{
Economic Analysis of Rice Value Chain in Bihar and Karnataka States of India
}

\author{
A.S. Pavithra, K.M. Singh, Nasim Ahmad", D.K. Sinha and R.R. Mishra \\ Department of Agricultural Economics, Dr. Rajendra Prasad Central Agricultural University, \\ Pusa, Samastipur-848 125, Bihar, India \\ *Corresponding author
}

\begin{tabular}{|l|}
\hline Ke y w o r d s \\
Rice, Value chain, \\
Marketing channel, \\
Production, \\
Consumption
\end{tabular}

\section{Introduction}

Agri-food systems are undergoing steady transformations and the emergence of integrated food supply chains is one of the most visible market phenomena in India. Increasing concentration on processing,

\begin{abstract}
A B S T R A C T
In Rice Value Chain, a value chain starts with the production of a primary commodity i.e. paddy (Farmers), ends with the consumption of the final product (rice and associated byproducts) and it includes all the economic activities undertaken between these phases such as processing, delivery, wholesaling, and retailing. A comparative study of value chain study of rice was undertaken in East Champaran district of Bihar and Davangere district of Karnataka. The districts were purposively selected because these districts were leading producers of rice and also on account of many rice mills are operating in these districts of respective states. The marketing channels III i.e. Producer - Itinerant Merchant - Miller - Wholesaler - Retailer -Consumer and channel VI i.e. Producer - Wholesaler (Paddy) - Miller - Wholesaler (Rice) Retailer - Consumer were found common marketing channel in East Champaran district of Bihar. In case of Davangere district of Karnataka, channel-I, i.e. Producer - Miller- Wholesaler- Retailer-Consumer was found most common channel of marketing. The farmers were the first actor in rice value chain, but they did not receive fair price. They have limited scope of value addition. Rice milling system was not developed; most of the rice mills were of traditional (huller). Only few were modern large rice mills and most of the rice millers were not economically sound to realize the full benefit of value chain in Champaran district (Bihar). Further, it was found that a number of modern large scale mills as well as traditional (huller) were operating in Davangere (Karnataka) on account of high production of rice in the state and it is grown in two seasons leading to sufficient inputs for rice mills in Karnataka. Rice millers were the highest and important value adder in rice value chain, rice millers were added value in three stages purchasing of paddy, milling of paddy and selling of rice.
\end{abstract}


Further, with increase in income, the pattern of food consumption is changing. Consumers are becoming more demanding in terms of quality and safety of food commodities. In addition, demographic and income trends are inducing more enlightened consumers to demand convenience foods together with assurances of product quality and safety. Consequently, production, processing and distribution systems are adapting to such changes (Kumar et al., 2011).

Rice is the most widely consumed staple food for a large part of the world's human population, especially in Asia. About four fifths of the world's rice is produced by small scale farmers and is consumed locally. India is the second largest producer of rice in the world after China, accounting for $20 \%$ of all world rice production. Not only, India is the second largest producer of rice but also it is the biggest consumer of rice in the world. It occupies about 22 per cent (43.39 million ha) of the total cultivated area in the country. India has the largest area under paddy in the world. Indian share in global rice production has been hovering around $20 \%$. Consumption estimates of rice has also gone up steadily from about 80-85 million tonnes in the early 2000s to about 104.32 million tonnes in 201516 (Anonymous, 2016).

The proportion of agricultural production that is, marketed by the farmers is an important indicator of commercialization of agriculture. The marketed surplus measured as a share of total production which is sold in the market is relatively higher in case of commercial crops than subsistence crops. In case of rice and wheat, increase in marketed surplus ratio has been mainly driven by effective government procurement policy, while in case of commercial crops like maize, vegetables, and oilseeds; it was due to the efforts of the private sector (Paul et al., 2015). Rice marketed surplus, ratio has increased by 15.5 percentage points i.e. from $61.7 \%$ in $1999-00$ to $77.2 \%$ in TE-2011-12).

Bihar and Karnataka are the two major rice growing states in India. Rice is cultivated all the 38 districts of Bihar. Out of these, 16 districts fall under high productivity group. The state has about 3.21 million hectare area under rice cultivation, with a production of 6.49 million tonnes during 2015-16, the state's average productivity is about $2019 \mathrm{~kg} / \mathrm{ha}$. The cost of cultivation of paddy was estimated at Rs. 33356.54during 2013-14. In Karnataka, rice is grown in 30 districts, out of which 14 are under high productivity group (yield more than $2,500 \mathrm{Kg} / \mathrm{ha}$ ). Karnataka has 1.06 million ha area under rice cultivation; the production of rice was 2.70 million tonnes during 201516. The state's average Productivity was 2547 $\mathrm{Kg} / \mathrm{ha}$, while, the cost of cultivation of rice in Karnataka was estimated as Rs 64283.05/ha in 2013-14 (Directorate of Economics and Statistics).

Agricultural value chain concept is the idea of actors connected along a chain producing and delivering goods to consumers through a sequence of activities. However, this "vertical" chain cannot function in isolation and an important aspect of the value chain approach is that it also considers "horizontal" impacts on the chain, such as input and finance provision, extension support and the general enabling environment (Humphrey, 2005).

Rice value chain focused on various value adding opportunities to ensure better price as well as demand-supply equilibrium. Various actors namely farmers, village trader, wholesaler, rice millers always concerned about their fair price besides improvement of rice quality. A series of value generating activities associated with product marketing from farm level to the ultimate consumer is referred to as value chain. The value chain 
activities of rice are carrying paddy from field after harvesting, threshing, cleaning, bagging, storing, carrying to the markets, selling to the traders, selling to the millers then millers converting paddy into rice, maintaining quality and grading. Rice millers are the starting actors in milling, bagging, transporting to different market, and selling to the ultimate consumer (Demont and Rizzotto, 2012; Hobbs and Fulto, 2000; Loosvelt and Defoer, 2010).

The paddy producers are mainly subsistence and semi subsistence in nature. Most farmers sell paddy immediately after harvest for fulfilling their cash requirements. But profit margins vary in the rice value chain due to market imperfections, unequal bargaining power among different actors, and unavailability of timely market information etc. If the actors know the benefit of participation in improved value chain, ensure optimum quality of paddy and rice, this in turn increases both actor's as well as ultimate consumer's welfare. Value-chain development and upgrading have significant implications on food security, poverty alleviation and overall economic development.

In this study, an effort has been made to analyze the value addition to rice in various marketing channels.

\section{Materials and Methods}

The present study was undertaken in East Champaran district of Bihar and Davangere district of Karnataka. The districts were purposively selected because these districts were leading producers of rice in their respective states

A list of rice producing blocks/taluks along with the area and production of rice in concerned block were prepared and out of the total blocks/taluks two blocks were selected randomly in both the states. Again a list of rice producers/farmers, paddy traders, processors, rice wholesalers, and rice retailers of every selected block was prepared. From each selected block, 50 producers and 5 each from paddy traders, processor, wholesalers, millers and retailers were selected randomly. Thus, a total of 150 respondents were selected for detailed investigation in each state. Marketing margin was calculated using the following formula:

Gross marketing margin $($ Rs/quintal $)=$ Sale price (Rs/quintal) - Purchase price (Rs/quintal)

Net margin (Rs/quintal) =Gross margin (Rs/quintal) - Marketing cost (Rs/quintal)

Value addition $(\%)=\frac{\text { Marketing Margin }}{\text { Purchase Price }} \times 100$

\section{Results and Discussion}

Value addition activities are mainly concerned with the changes of utilities. In economics, the sum of the unit profit, the unit depreciation cost, and the unit labour cost is the unit value added.

A conceptual diagram of rice value chain network has been conceptualized according to core processes involved i.e. Farmer, commission agent, miller (paddy processors), retailer and finally consumers. It can be seen from the network that in spite of diversified movement of produce to various actors, paddy has to move to millers for further movement to the consumer.

\section{Marketing channel involved in marketing of rice}

After the harvesting of paddy, the produce is dried and marketed to various stake holders after bagging. After the post-harvest operations such as drying, bagging the 
produce, paddy is ready for marketing. Apart from the main product Paddy the byproduct paddy straw was mainly used as a fodder for the cattle. It is seen from the conceptual diagram that paddy from various stakeholders has to go to miller.

The study identified various marketing channel of paddy, rice and its associated byproducts in respective study area. Two different marketing channels were found most common in the study area. First, paddy marketing channel which was producers to miller and second, was rice marketing channel millers to ultimate consumers. Various types of marketing channels identified in East Champaran and Davangere districts were reported in Table 1 with reference to corresponding respondent preference. Channel-III and IV were found common marketing channel in East Champaran district of Bihar. In case of Davangere district of Karnataka channel-I was found most common channel of marketing. This may be due to a large number of mills are operating in its surrounding/vicinity of Davangere and thus, millers were directly purchasing produce from farmers.

Each producer selected marketing channel based on various reasons, the reason behind the selection of marketing channel were mainly, economic condition of the farmers or family condition, and prices prevailing in the market were the important reason behind selecting the effective marketing channel. Even though they were facing many problems still some of the farmers tried to select good marketing channel to get better price

\section{Value addition to paddy by farmers}

Table 2 revealed that the paddy price was comparatively low in East Champaran than in Davangere district. Farmers of East Champaran district sold their produce below the minimum support price. But in Davangere district farmers sold their produce at various competitive market prices. The farmers were adding value through drying, marketing and storing of paddy. The value addition done through these activities was found to be 10.00 per cent amounting to Rs 115.71 in case of value addition due to drying, and value addition due to marketing of produce was estimated at 7.49 per cent amounting to Rs 86.77 and 10.99 per cent amounting to Rs 127.7 in case of storing of produce, in East Champaran district of Bihar. It was found that value addition done by farmer through storing of paddy was high and more profitable (market margin 127.27 Rs/ql) than to drying and marketing of produce, and it was similar in case of Davangere district of Karnataka. The farmers performed same activities and added value to the extent of 8.0 per cent amounting to Rs $132.85,7.45$ per cent amounting to Rs 123.9 and 9.98 per cent amounting to Rs 165.9 in case of drying, marketing and storing of produce respectively.

\section{Value addition of paddy wholesalers}

Table 3 showed that, in both the study area, average purchasing price of paddy wholesalers was Rs. 1191.82/q and whereas average selling price of paddy was found to be Rs. $1257.62 / q$. Average value addition by the paddy wholesalers was Rs 65.8 /q which was $5.52 \%$ of total cost in case of East Champaran district. The price of paddy was very less in East Champaran district it might be due to farmers sold their produce on MSP or below MSP, and many of the government procuring centers were not in function and the most important reason was absence of regulated markets in Bihar that is why farmers were not getting remunerative price for their produce. In Davangere district (Karnataka), it was found that average purchasing price was Rs 1748.66/q and average selling price was Rs $1824.33 / q$, respectively and average value 
addition was Rs $75.67 / \mathrm{q}$ which was $4.3 \%$. The total marketing cost of paddy was Rs 56.6 /q and Rs 59.04 /q. Total marketing cost included variable cost Rs. 38 /ql and Rs 45.79 /q, and fixed cost accounts for Rs 17.6 /ql and Rs 13.25 /q, respectively in East Champaran and Davangere district. It was observed that value addition by paddy wholesalers in East Champaran District was more than Davangere district.

\section{Value addition to paddy by rice miller (processor)}

The produce once after moving to mills, paddy is processed to either obtain the raw rice or parboiled rice. For this mills are of two kinds where milling units can only produce raw rice by performing milling process. While the parboiled rice mills provide for both parboiling and then milling i.e. parboiled mills can produce both parboiled rice and raw rice.

Rice millers were the important player in rice value chain. They were the more value adder in the rice value chain. The main part of the rice value chain work takes place in rice mills only by converting paddy into rice. In the study it was observed that rice millers were adding value to rice in three different forms i.e. in purchasing of paddy, milling of paddy, and selling of rice. It was observed that in the area under study rice milling system was not developed.

Most of the rice mills were of traditional (huller) in East Champaran district (Bihar) and only few were modern large rice mills and most of the rice millers were not economically sound to realize the full benefit of value chain. In Davangere district (Karnataka) it was found that a number of modern large scale mills as well as traditional (huller) were operating. The presence of large number of rice mills was due to the high production of rice in the state and it is grown in two seasons due to this reason there was no shortage of inputs for rice millers in Karnataka.

Table 4 showed that products obtain from one quintal of paddy and price of produce, were found different in main product production in respective study area. The fine rice obtained from one quintal of paddy was $66.1 \mathrm{~kg}$ and $69.5 \mathrm{~kg}$ and per unit price of fine rice was Rs 29.86 and Rs 34.7 per unit in East Champaran and Davangere district, respectively and including other by-products price, total income from one quintal of paddy was Rs 2343.81 in East Champaran and Rs 2843.97 in Davangere, respectively.

Table 5 showed that rice millers added value of total Rs 1042.73 and Rs 1068.12 by purchasing paddy, converting paddy in rice and rice marketing in East Champaran and Davangere district. They added 81.21 per cent and 60.63 per cent extra value for their whole activities in respective study area. Value addition was calculated based on per quintal paddy and final selling price calculated and summing up the selling price of products produced from conversion of 1 quintal paddy i.e. rice, bran, husk and broken rice.

To obtain one quintal rice, millers have to use about 1.51quintal and 1.43 quintal of paddy which added value of about Rs 1045.08 and Rs 935.34 in East Champaran and Davangere district respectively.

\section{Value addition by rice wholesalers}

Rice wholesalers have limited opportunity to add value among all other value adding actors. Purchasing price of rice to rice wholesaler was Rs 3027.48/q and Rs 3734.33 /ql; selling price was Rs 3351.40/q and Rs 4147.12/q in East Champaran and Davangere district. The value addition was found to be $10.69 \%$ (Rs $323.92 / q)$ and $11.05 \%$ (Rs 412.79/q) of rice in both the states respectively (Table 6). 
Table.1 Rice marketing channel in respective study area

\begin{tabular}{|c|c|c|c|}
\hline \multirow{2}{*}{$\begin{array}{l}\text { Sl. } \\
\text { No }\end{array}$} & \multirow[t]{2}{*}{ Market channel } & \multicolumn{2}{|c|}{ No. of respondents } \\
\hline & & East Champaran & Davangere \\
\hline$\cdot$ & Producer - Miller-Wholesaler - -Retailer-Consumer. & 18 & 46 \\
\hline . & $\begin{array}{l}\text { Producer-Commission } \quad \text { Agent-Miller-Wholesaler } \\
\text { Retailer-Consumer. }\end{array}$ & - & 18 \\
\hline • & $\begin{array}{l}\text { Producer - Itinerant Merchant - Miller - Wholesaler - } \\
\text { Retailer -Consumer. }\end{array}$ & 28 & - \\
\hline • & $\begin{array}{l}\text { Producer - Wholesaler (Paddy) - Miller - Wholesaler } \\
\text { (Rice) Retailer - Consumer. }\end{array}$ & 28 & 22 \\
\hline - & Producer - Miller - Retailer - Consumer & 26 & 10 \\
\hline$\cdot$ & Producer - Miller -Consumer & - & 4 \\
\hline & Total & 100 & 100 \\
\hline
\end{tabular}

Table.2 Value Addition to Paddy by farmer in by different activities in East Champaran (Bihar) and Davangere (Karnataka)

\begin{tabular}{|c|c|c|c|c|c|}
\hline \multirow{2}{*}{$\begin{array}{l}\text { Value addition } \\
\text { activity }\end{array}$} & \multirow[t]{2}{*}{ Price } & \multicolumn{2}{|c|}{ East Champaran (Bihar) } & \multicolumn{2}{|c|}{ Davangere (Karnataka) } \\
\hline & & $\begin{array}{c}\text { Value } \\
\text { addition } \\
(\mathrm{Rs} / \mathrm{q})\end{array}$ & $\begin{array}{c}\text { Value } \\
\text { addition } \\
(\%)\end{array}$ & $\begin{array}{c}\text { Value } \\
\text { addition } \\
(\mathrm{Rs} / \mathrm{q})\end{array}$ & $\begin{array}{c}\text { Value } \\
\text { addition (\%) }\end{array}$ \\
\hline \multirow{5}{*}{$\begin{array}{l}\text { Value addition } \\
\text { due to drying }\end{array}$} & Wet paddy Price & 1157.03 & \multirow[t]{5}{*}{10.00} & 1660.50 & \multirow[t]{5}{*}{8.0} \\
\hline & Dry paddy price & 1272.74 & & 1793.35 & \\
\hline & Drying cost & 8.62 & & 13.22 & \\
\hline & $\begin{array}{l}\text { Marketing margin } \\
\text { (value addition) }\end{array}$ & 115.71 & & 132.85 & \\
\hline & Net marketing margin & 107.09 & & 119.63 & \\
\hline \multirow{5}{*}{$\begin{array}{c}\text { Value addition } \\
\text { due to } \\
\text { marketing }\end{array}$} & $\begin{array}{l}\text { Farm gate price of } \\
\text { paddy }\end{array}$ & 1157.03 & \multirow[t]{5}{*}{7.49} & 1661.10 & \multirow[t]{5}{*}{7.45} \\
\hline & Market price of paddy & 1243.80 & & 1785 & \\
\hline & Marketing cost & 14.89 & & 20.49 & \\
\hline & $\begin{array}{l}\text { Marketing margin } \\
\text { (value addition) }\end{array}$ & 86.77 & & 123.9 & \\
\hline & Net marketing margin & 71.88 & & 103.41 & \\
\hline \multirow{5}{*}{$\begin{array}{c}\text { Value addition } \\
\text { due to storing } \\
\text { Paddy }\end{array}$} & $\begin{array}{l}\text { Price before storing } \\
\text { paddy }\end{array}$ & 1157.03 & \multirow[t]{5}{*}{10.99} & 1661.10 & \multirow[t]{5}{*}{9.98} \\
\hline & $\begin{array}{l}\text { Price after storing } \\
\text { (average } 3 \text { months) }\end{array}$ & 1284.30 & & 1827.00 & \\
\hline & $\begin{array}{l}\text { Storing and marketing } \\
\text { Cost }\end{array}$ & 18.13 & & 50.49 & \\
\hline & $\begin{array}{l}\text { Marketing margin } \\
\text { (value addition) }\end{array}$ & 127.27 & & 165.9 & \\
\hline & Net marketing margin & 109.14 & & 115.41 & \\
\hline
\end{tabular}


Table.3 Marketing costs, margins and value addition by paddy wholesalers

\begin{tabular}{|c|c|c|c|c|c|c|c|}
\hline \multirow{2}{*}{\multicolumn{2}{|c|}{ Items }} & \multicolumn{3}{|c|}{ East Champaran (Bihar) } & \multicolumn{3}{|c|}{ Davangere (Karnataka) } \\
\hline & & $\mathrm{Rs} / \mathrm{ql}$ & $\begin{array}{l}\text { Value } \\
\text { addition }\end{array}$ & $\begin{array}{c}\text { Marketing } \\
\text { margin } \\
(\%)\end{array}$ & Rs/quintal & $\begin{array}{c}\text { Value } \\
\text { addition }\end{array}$ & $\begin{array}{c}\text { Marketing } \\
\text { margin } \\
(\%)\end{array}$ \\
\hline \multirow{2}{*}{\multicolumn{2}{|c|}{$\begin{array}{l}\text { Purchase price of paddy } \\
\text { Selling price of paddy }\end{array}$}} & 1191.82 & \multirow[t]{8}{*}{5.52} & & 1748.66 & \multirow[t]{8}{*}{4.32} & \\
\hline & & 1257.62 & & & 1824.33 & & \\
\hline \multirow{3}{*}{$\begin{array}{l}\text { Marketin } \\
\text { g cost }\end{array}$} & Variable cost & 38 & & 57.75 & 45.79 & & 60.51 \\
\hline & Fixed cost & 17.6 & & 31.09 & 13.25 & & 17.65 \\
\hline & Total & 56.6 & & 86.01 & 59.04 & & 78.02 \\
\hline \multicolumn{2}{|c|}{$\begin{array}{l}\text { Value addition } \\
\text { (marketing margin) }\end{array}$} & 65.8 & & 100 & 75.67 & & 100 \\
\hline \multicolumn{2}{|c|}{ Gross Margin } & 27.8 & & 42.24 & 29.88 & & 39.48 \\
\hline \multicolumn{2}{|c|}{ Net Margin } & 9.2 & & 13.98 & 16.63 & & 21.97 \\
\hline
\end{tabular}

Table.4 Products obtained from one quintal paddy

\begin{tabular}{|l|c|c|c|c|c|}
\hline Products & Amount(Kg) & \% of total & Per unit price & Total value \\
\hline & \multicolumn{3}{|c|}{ East Champaran, Bihar } \\
\hline Rice & 66.1 & 66.1 & 29.86 & 1973.74 \\
\hline Broken rice & 6.35 & 5.95 & 15.24 & 96.77 \\
\hline Bran & 5.25 & 5.25 & 11.12 & 58.38 \\
\hline Husk & 21.6 & 18.7 & 9.95 & 214.92 \\
\hline Weight loss & 0.7 & 0.7 & - & 17.19 \\
\hline Total & 100 & 100 & & 2343.81 \\
\hline & & Davangere, Karnataka & & 2411.65 \\
\hline Rice & 69.5 & 69.5 & 34.7 & 122.74 \\
\hline Broken rice & 6.8 & 6.8 & 18.05 & 66.79 \\
\hline Bran & 5.4 & 5.4 & 12.37 & 242.79 \\
\hline Husk & 17.8 & 17.8 & 13.64 & 14.20 \\
\hline Weight loss & 0.5 & 0.5 & - & 2843.97 \\
\hline Total & 100 & 100 & & \\
\hline
\end{tabular}


Table.5 Costs and margins, value addition of rice millers

\begin{tabular}{|c|c|c|c|c|c|c|c|}
\hline \multirow{2}{*}{\multicolumn{2}{|c|}{ Item }} & \multicolumn{3}{|c|}{ East Champaran (Bihar) } & \multicolumn{3}{|c|}{ Davangere (Karnataka) } \\
\hline & & \multicolumn{2}{|c|}{ Rs/q } & \multirow{3}{*}{$\begin{array}{c}\text { Value } \\
\text { addition (\%) } \\
5.46\end{array}$} & \multicolumn{2}{|c|}{ Rs/q } & \multirow{3}{*}{$\begin{array}{c}\text { Value } \\
\text { addition (\%) } \\
6.92\end{array}$} \\
\hline \multirow{2}{*}{$\begin{array}{l}\text { Purchasing cost of } \\
\text { paddy (i) }\end{array}$} & Variable cost & 44.53 & \multirow[t]{2}{*}{57.03} & & 59.72 & \multirow[t]{2}{*}{74.02} & \\
\hline & Fixed cost & 12.5 & & & 14.3 & & \\
\hline \multicolumn{2}{|c|}{ Milling cost of paddy (ii) } & \multicolumn{2}{|c|}{183.5} & 17.59 & \multicolumn{2}{|c|}{234.41} & 21.94 \\
\hline \multicolumn{2}{|l|}{ Selling cost of rice (iii) } & \multicolumn{2}{|c|}{36.39} & 3.48 & \multicolumn{2}{|c|}{43.58} & 4.08 \\
\hline \multicolumn{2}{|c|}{ Gross cost $(\mathbf{i v})=(\mathbf{i})+(\mathrm{ii})+(\mathrm{iii})$} & \multicolumn{2}{|c|}{276.92} & 26.55 & \multicolumn{2}{|c|}{352.01} & 32.95 \\
\hline \multirow{2}{*}{$\begin{array}{l}\text { Purchase price of } \\
\text { paddy }(v)\end{array}$} & Farmers & \multicolumn{2}{|c|}{1217.86} & \multirow[t]{2}{*}{1283.89} & \multicolumn{2}{|c|}{1759.82} & 1761.65 \\
\hline & Paddy wholesalers & \multicolumn{2}{|c|}{1386.12} & & \multicolumn{2}{|c|}{1765.31} & \\
\hline \multicolumn{2}{|c|}{$\begin{array}{l}\text { Return from paddy (vi) (rice and by - } \\
\text { product price) }\end{array}$} & \multicolumn{2}{|c|}{2343.81} & & \multicolumn{2}{|c|}{2843.97} & \\
\hline \multicolumn{2}{|c|}{ Weight loss (vii) } & \multicolumn{2}{|c|}{17.19} & & \multicolumn{2}{|c|}{14.20} & \\
\hline \multicolumn{2}{|c|}{$\begin{array}{l}\text { Total return excluding losses (viii)=(vi) - } \\
\text { (vii) }\end{array}$} & \multicolumn{2}{|c|}{2326.62} & & \multicolumn{2}{|c|}{2829.77} & \\
\hline \multicolumn{2}{|c|}{$\begin{array}{l}\text { Marketing margin (value addition) }(\mathrm{ix})= \\
\text { (viii) }-(\mathrm{v})\end{array}$} & \multicolumn{2}{|c|}{1042.73} & 81.21 & \multicolumn{2}{|c|}{1068.12} & 60.63 \\
\hline \multicolumn{2}{|c|}{ Net marketing margin ((x) } & & & 2.28 & & & 1.98 \\
\hline
\end{tabular}

Note: (Return from one quintal paddy was calculated by adding all the selling of main product and byproducts obtained from paddy i.e. rice, bran, husk and broken rice. Weight loss was deducted from total return.)

Table.6 Value addition to per unit rice by miller

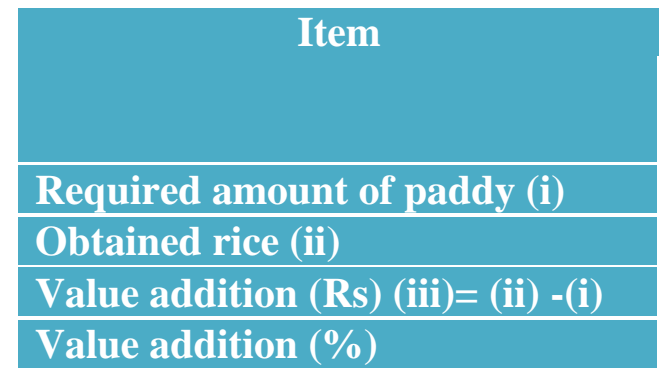

\begin{tabular}{|c|c|c|c|}
\hline \multicolumn{2}{|c|}{ East Champaran (Bihar) } & \multicolumn{2}{|c|}{ Davangere (Karnataka) } \\
\hline $\begin{array}{l}\text { Amount } \\
(\mathrm{kg})\end{array}$ & $\begin{array}{c}\text { Total value } \\
\text { (Rs) }\end{array}$ & $\begin{array}{l}\text { Amount } \\
(\mathrm{kg})\end{array}$ & $\begin{array}{l}\text { Total value } \\
\text { (Rs) }\end{array}$ \\
\hline 151.28 & 1940.92 & 143.88 & 2534.66 \\
\hline 100 & 2986 & 100 & 3470 \\
\hline \multicolumn{2}{|c|}{1045.08} & 935.34 & \\
\hline \multicolumn{2}{|c|}{53.84} & 36.90 & \\
\hline
\end{tabular}

\section{Conceptual diagram of rice-value chain}

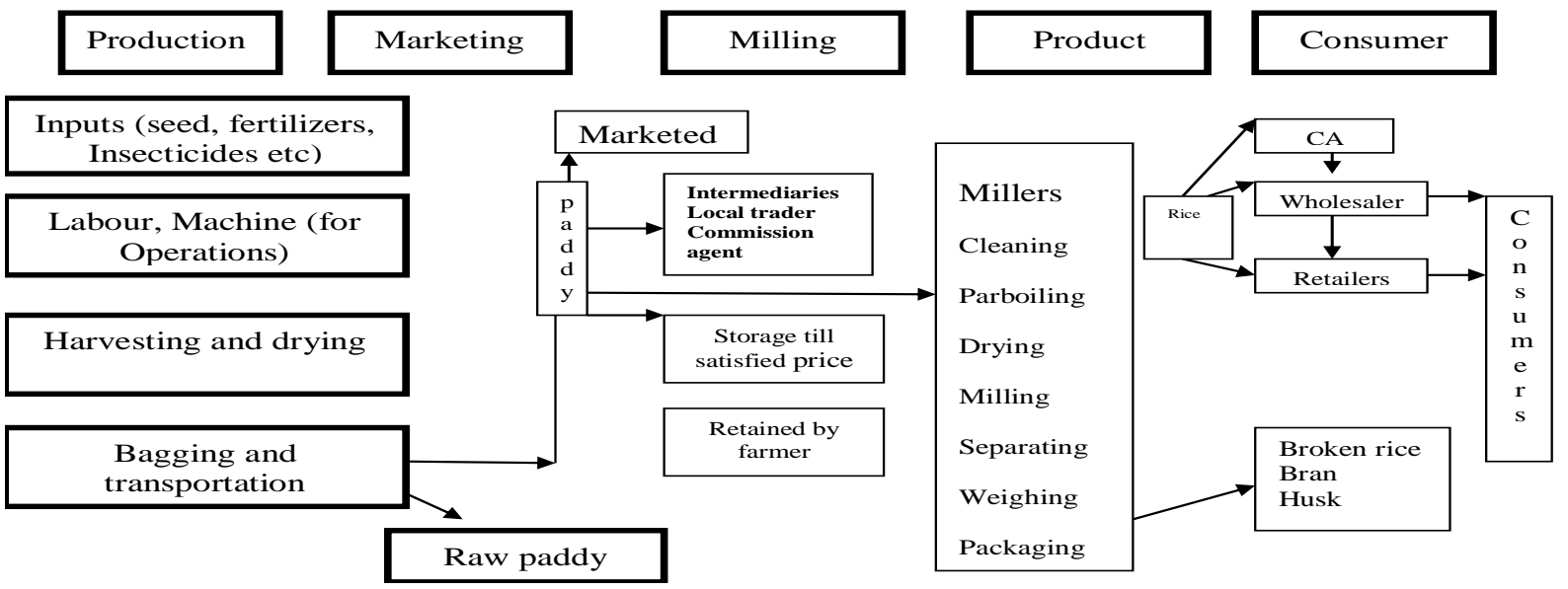


Net margin or profit of rice wholesalers was found to be Rs 238.42/q and Rs 311.98/q and the profits were Rs $2.38 / \mathrm{kg}$ and $\mathrm{Rs} 3.11 / \mathrm{kg}$ of rice respectively in East Champaran district of Bihar and Davangere district of Karnataka

\section{Value addition to rice by retailers}

Rice retailers were the final actor in the rice value chain and they were the important source for rice to common people in the society. The total marketing cost of rice retailers in the respective states constituted Rs 50.97/q and Rs 48.99 /q, which included total variable cost of Rs 37.63/q and Rs 41.52/q and total fixed cost Rs 13.34 /q and Rs 7.47 /q in East Champaran and Davangere districts respectively. Rice retailers were also paying more money for transportation of rice and accounting to Rs 17.31 /q in East Champaran district and Rs 20.09 /q in Davangere district. The study pointed out that in case of East Champaran district retailer's expenditure in marketing of rice was more than that of Davangere district, it might be due to the existence of very few rice mills in East Champaran, resulting in more expenses for procurement and other marketing activities. The existence of more rice mills in Davangere retailers obtained less cost as compared to East Champaran rice retailers.

It was reflected from the foregoing discussion that the stakeholders involved in rice value marketing chains were commission agents, paddy wholesalers, millers, rice wholesalers and rice retailers. It was observed that the selling of paddy from farmers to rice millers, farmers were fetching better price and were also getting produce on economic price as it was better option to purchase directly from producer than from paddy traders. In this study, it was felt that this was the efficient and effective shorter value chain in which farmers got maximum value of paddy in both the states under study.

The findings of the present study revealed that the producers could not manage expected net margin due to high cost of production and low output price. Most of the production was consumed by the farmers. Some large farmers stored paddy and later sold in the market. The farmers and intermediaries could certainly be benefited financially if production and marketing system of rice were well developed.

It was found that products obtain from one quintal of paddy and price of produce, were found different in main product production in respective study area. The fine rice obtained from one quintal of paddy was $66.1 \mathrm{~kg}$ and $69.5 \mathrm{~kg}$ and per unit and the price of fine rice were Rs 29.86 and Rs 34.7 per unit in East Champaran and Davangere district, respectively and including other by-products price. Total income from one quintal of paddy was Rs 2343.81 in East Champaran and Rs 2843.97 in Davangere, respectively.

The farmers were the first actor in rice value chain, but they did not receive fair price. They have limited scope of value addition. It was also observed that in the area under study rice milling system was not developed. Most of the rice mills were of traditional (huller) in East Champaran district (Bihar) and only few were modern large rice mills and most of the rice millers were not economically sound to realize the full benefit of value chain. In Davangere district (Karnataka) it was found that a number of modern large scale mills as well as traditional (huller) were operating. The presence of large number of rice mills was due to the high production of rice in the state and it is grown in two seasons due to this reason there was no shortage of inputs for rice millers in Karnataka.

The priority attention by the government may be given to the farmers so that they can contribute largely in the value chain.

\section{Policy implications}

On the basis of finding, the following policy suggestions were made for the development of rice value chain in respective study areas, which are mentioned here under:

Post-harvest handling and value addition. 
On time supply of inputs during cultivation with subsidized rate.

Investing in infrastructure to ensure postharvest product quality.

Support to enhance the cooperative processing (milling) industry in rural area by farmers.

Longer value chains mean smaller stakeholder profit, so efforts may be made to shorten the value chains. Emphasis on effective shorter value chain.

Efficient intervention by Government in market chain (Establishment of Regulated market and proper market infrastructure) in case of Bihar.

Strengthen market linkages.

Support the development of sustainable value chain financing.

Financial Support for the establishment of small scale milling industry in rural area.

Strengthen the partnership between government and private sector.

Enhance support to transform subsistence system to commercial system

Direct procurement of rice from millers by organized retailers would help to reduce price of rice.

Expand facilities to PACS for efficient work (procurement of produce at MSP in case of East Champaran district). Establishment of rural godowns and expand the existing godowns in study area.

\section{References}

Agricultural Statistics at a Glance (2016). Directorate of Economics and Statistics, Ministry of Agriculture and Farmers Welfare, Govt. of India

Demont and Rizzotto, 2012. Policy Sequencing and the Development of Rice Value chains in Sengal. Development Policy Review. 30(4):451-472

Hobbs, Cooney, A and Fulto M, 2000. Value chains in the agri-food sector. College of Agriculture, University of Saskaatchewin, Saskatoon, Canada.

Humphrey, J. 2005. Shaping Value Chains for Development: Global Value Chains in Agribusiness. Trade Programme, Div. 41 Economic Development and Employment. Eschborn 2005.

Kumar Anjani Singh Harbir, Kumar Sant and Mittal Surabhi, 2011. Value Chains of Agricultural Commodities and their Role in Food Security and Poverty Alleviation - A Synthesis. Agricultural Economics Research Review Vol. 24. pp 169-181.

Loosvelt and Defoer, 2010. The rice agriObusiness cluster in the upper East region in Ghana. The outcomes of the capitalization workshop of agribusiness cluster development; 27-30 September 2010

Paul Sharma, V and Wardhan Harsh, 2015. Assessment of marketed and marketable surplus of major food grains in India. Report submitted to, Centre for Management in Agriculture, Indian Institute of Management (IIM), Ahmadabad.

\section{How to cite this article:}

Pavithra, A.S., K.M. Singh, Nasim Ahmad, D.K. Sinha and Mishra, R.R. 2018. Economic Analysis of Rice Value Chain in Bihar and Karnataka States of India. Int.J.Curr.Microbiol.App.Sci. 7(03): 2738-2747. doi: https://doi.org/10.20546/ijcmas.2018.703.316 